\title{
SETTING ASIDE PRIVATE NON-LABOUR ARBITRATION AWARDS FOR ERRORS OF LAW - SOME RECENT DECISIONS
}

\author{
W.H. HURLBURT*
}

\begin{abstract}
The author discusses recent cases concerning judicial review of private arbitration awards for errors of law. The author discusses in particular the patent unreasonability test and final and binding clauses.
\end{abstract}

\section{INTRODUCTION}

Has an arbitrator in a private non-labour arbitration who makes an error of law on the face of the award "misconducted himself" so that the Court of Queen's Bench may set aside the award under section 11(2) of the Arbitration Act (Alberta), or has he "misconducted himself" only if the error of law is "patently unreasonable" ?' This note addresses that narrow question in the light of a number of recent decisions of the Court of Queen's Bench, the Court of Appeal and the Supreme Court of Canada. It is not about underlying policy but about the workings of the rules of precedent.

\section{DEVELOPMENT OF THE LAW}

The "patently unreasonable" test is a creation of administrative law. It was devised to decide whether a statutory delegate has committed an error in law which is "jurisdictional in nature, and therefore cannot be immunized from judicial review by a privative clause."2 The question is whether it has been transported across to judicial supervision of private non-labour arbitrators.

Historically, there has been no "patently unreasonable" test for private non-labour arbitrations. Section 11(1) of the Arbitration Act (Alberta) provides that the Court of Queen's Bench may set aside an arbitrator's award if the arbitrator has "misconducted himself". It is a faithful copy of the Arbitration Act 1889 (UK). Before 1889, the courts had held that misconduct occurs "if the award ... is on its face erroneous in matter of law.'3 Until the Arbitration Act 1979 (U.K.) changed the law, English courts applied the same test under the 1889 Act and its successors and set awards aside for error of law on the face. Almost to the present day,

- Director Emeritus and consultant, Institute of Law Research and Reform and of counsel, Reynolds, Mirth, Richards and Farmer, Edmonton. The author is grateful to Professor D.P. Jones, Q.C. for his helpful and constructive comments on an earlier draft of this note.

1. There are a number of alternative pejoratives which will be mentioned below. "Patently unreasonable" is fashionable and will therefore be used in this note.

2. Jones \& de Villars, Principles of Administrative Law (1985) 283. It should be noted that much that is said in this note is also said by Jones \& de Villars, who cover much of its ground, particularly at pages 305-309. This note looks at the subject from the private non-labour arbitration side and from the point of view of a lawyer who has not had much exposure to the horrors of administrative law or of the administrative law concepts of jurisdiction.

3. 1 Halsbury (1st ed.) 478-479. The authorities cited are pre-1889.

4. Under the appeal procedure under the 1979 UK Act, the High Court, while it may be somewhat more liberal under a standard form contract, should not grant leave to appeal in an arbitration involving a unique contract unless the arbitrator is so clearly wrong that it is not possible that the court could be persuaded that he is right: The Nema [1981] 2 All E.R. 1030. 
Canadian courts have done the same. R.O.M. Construction Ltd. v. Electric Power Equipment Ltd. ${ }^{s}$ is a recent example.

In the meantime, arbitration has become an important tool in the law of labour relations. Sometimes a labour law statute establishes an arbitral tribunal to which the parties must resort. Sometimes it leaves an option to the parties to provide for the settlement of disputes by arbitration or otherwise. Sometimes it includes a special privative clause to preclude or at least to limit judicial review. Sometimes it does not. What it does characteristically do is to establish an "all-embracing scheme for the establishment and furtherance of labour relations in the interest of the community at large as well as in the interests of the parties to labour relations" ${ }^{6}$ The existence of such a scheme is the backdrop against which the labour arbitrations decisions mentioned below should be interpreted.

\section{SOME JUDICIAL DECISIONS}

It is now time to turn to some recent decisions of the Supreme Court of Canada and of the Alberta courts. The first, C.U.P.E. v. New Brunswick Liquor Corp. ${ }^{7}$ is treated as the classic statement of the "patently unreasonable" test. It was a certiorari case. The question was whether the employer was entitled to replace workers with management employees during a strike and the answer depended upon the interpretation of the New Brunswick Public Service Labour Relations Act. Chief Justice Dickson, speaking for the Court, treated the question as one of the jurisdiction of the arbitrators and posed the question as follows:

Did the Board here so misinterpret the provisions of the Act as to embark on an inquiry or answer a question not remitted to it? Put another way, was the Board's interpretation so patently unreasonable that its construction cannot be rationally supported by the relevant legislation and demands intervention by the Court upon review?

The next case, Volvo Canada Ltd. v. International Union, United Automobile, Aerospace \& Agricultural Implement Workers of America ${ }^{8}$, involved an application under the Nova Scotia Arbitration Act to set aside an award which rejected a grievance under a collective labour agreement. The grievance was based on the proposition that absence from work during a strike was a "justifiable reason" for absence within the meaning of the agreement and that the employee's seniority therefore continued to accrue during the strike.

The reasons of the majority of the Court were given by Mr. Justice Pigeon. The following passage from his judgment is part of the Court's ratio decidendi:

It is therefore imperative that decisions on a collective agreement not be approached by asking how the Court would decide the point but by asking whether it is a "patently unreasonable" interpretation of the agreement.

Mr. Justice Pigeon then referred to the application of that criterion by the Supreme Court in the C.U.P.E. case.

5. [1981] 4 W.W.R. 97 (Alta. C.A.).

6. St. Anne Nackawic Pulp \& Paper Co. Ltd. v. Canadian Paper Workers' Union [1986] 1 S.C.R. 704, per Estey J., speaking for the court, page 718.

7. (1980) 97 D.L.R. (3rd) 417 (S.C.C.).

8. (1980) 99 D.L.R. (3d) 193 (S.C.C.). 
It will be noted that Mr. Justice Pigeon spoke only of collective agreements and not of other agreements which provide for arbitration. The Volvo case is therefore authority only upon the interpretation of a collective agreement and does not apply to a private non-labour arbitration.9

The Alberta Court of Appeal considered the Volvo case in R.O.M. Construction Ltd. v. Electric Power Equipment Ltd. ${ }^{10}$ This involved a private non-labour arbitration under the Arbitration Act (Alberta). Mr. Justice Kerans, in giving the judgment of the Court, first referred to the rule that an award can be set aside for error of law on its face. He went on to say that the Volvo case had put the rule in doubt. However, he did not agree that it had said that in the interpretation of a contract term the test in consensual as well as compulsory arbitrations was not whether an arbitrator has committed any error in law but whether his error was patently unreasonable. "It is difficult", he said, "to accept that the Supreme Court would change a long-standing rule without acknowledging that it is doing so. I prefer the view that the new rule was intended to apply only to collective agreements". The Supreme Court did not pick up the gauntlet: it refused leave to appeal."

Mr. Justice Kerans also delivered the judgment of the Court of Appeal in the next case which arises for consideration, Suncor Inc. v. McMurray Independent Oil Workers. ${ }^{12}$ This was an appeal from an order of certiorari quashing an award under a collective agreement. The standard of review, he said, was the same whether the arbitration was consensual or imposed. However the reason was that section 129 of the Labour Relations Act (Alberta) applied to all collective agreement arbitrations, whether consensual or not, and the judge said that it was "not at all clear" that the standard of review' for consensual arbitration is, at common law, "sterner than "error of law on the face of the record"" and referred to the R.O.M. case.

The next case, Shalansky v. Regina Pasqua Hospital ${ }^{14}$ is crucial to the discussion. It involved the interpretation of a collective agreement, but Chief Justice Laskin, who gave the judgment of the Supreme Court, said that the arbitration was a "consensual" arbitration under a "voluntary" collective agreement, and that "we are not trammelled by any certiorari question or by any other statutory considerations."

Having held that there was no special question of law referred to the arbitrators, the Chief Justice went on to approve the approach taken in the Saskatchewan Court of Appeal by Chief Justice Bayda, ${ }^{\text {is }}$ who had held that there were two reasonable constructions of the collective agreement in

9. This was the view taken by MacLaren and Palmer on Commercial Arbitration, Carswell, 1982, 119; by the Alberta Court of Appeal in the R.O.M. case (supra note 5); and by the Saskatchewan Court of Appeal in the Shalansky case (infra note 14).

10. Supra, note 5 .

11. 121 D.L.R. (3rd) 753.

12. [1983] 1 W.W.R. 604 (Alta. C.A.).

13. I.e., what degree of error the applicant must show in order to succeed.

14. [1983] 1 S.C.R. 303.

15. (1982) 15 Sask. R. 253. 
question and that the arbitrators were entitled to choose between them, even though, in Chief Justice Bayda's opinion, they had made the wrong choice. In the course of his reasons for judgment, Chief Justice Laskin said that there is no significant difference between the terms "outrageous", "patently unjustifiable", and "patently unreasonable". He went on to say that, "apart from a question of emphasis, the test of unreasonableness or test of clearly wrong is also not different".

It is sensible to equate the three more violent pejoratives. It may also be sensible to take the next step and equate "unreasonableness" with "patent unreasonableness", but it must then follow that "patently unreasonable" merely means "unreasonable" with the addition of an abusive epithet, or, as Chief Justice Laskin seems to have put it, "unreasonable" with additional emphasis. It may also be sensible to describe the test, as Chief Justice Laskin went on to do, as being whether or not the arbitrator's interpretation is one "which the words of the agreement could not reasonably bear". This is consistent with treating all pejoratives having to do with outrage or unreasonableness as meaning the same thing.

However, it is one thing to say that all terms involving reasonableness, with or without pejorative adjectives, amount to the same thing, but quite another thing to say that reasonableness and rightness are the same thing. If they are, courts and commentators have wasted much time and energy to no account and no doubt will continue to do so. But it is clear that at least some judges have found arbitrators' awards to be wrong but not to be patently unreasonable and have therefore not interfered with them. The decision of the Saskatchewan Court of Appeal in the Shalansky case itself is an example. This is at least some evidence that there is a difference between wrongness and patent unreasonableness, and it seems that they should be regarded as different qualities.

Chief Justice Laskin's penultimate paragraph in the Shalansky case is also important to this inquiry. Chief Justice Bayda had said ${ }^{16}$ that a series of Supreme Court of Canada decisions, which included the Volvo decision, had created a special category of case in which "the issue submitted to the arbitrator constitutes a grievance in the course of whose determination questions of construction of the collective bargaining agreement arose".

In reply to this, Chief Justice Laskin said: ${ }^{17}$

Once it is accepted that there are two reasonable interpretations, the suggestion of a reviewable error of law in consensual arbitration disappears. There is no need to construct a third category, namely, reference to an arbitrator involving construction of a collective agreement. The principle on which this so-called third category is founded is the very principle applicable in all consensual arbitration cases. The decision of the arbitrator can be set aside only if involves an interpretation which the words of the agreement could not reasonably bear. ${ }^{18}$

16. Id. at 264.

17. Supra, note 14 at 307.

18. Emphasis added. 
The Alberta Queen's Bench has since applied the "patently unreasonable" test to awards in at least three private non-labour arbitrations. ${ }^{19}$ In the Loyal Electric case, Mr. Justice McNaughton referred to the R.O.M. case and then said that the Shalansky case sets the "higher" standard which the applicant must meet if he is to obtain judicial review, i.e., the "patently unreasonable" standard, thus apparently holding that the former had been overridden by the latter. All three Queen's Bench decisions took a novel point: that section 8 of the Schedule to the Arbitration Act, which provides that an award is final and binding, is a privative clause.

\section{APPLICATION OF THE "PATENTLY UNREASONABLE" TEST TO PRIVATE NON-LABOUR ARBITRATIONS}

There are three possible answers to the question whether the Supreme Court of Canada has held authoritatively that, at least in some cases, the award of an arbitrator in a private non-labour arbitration under an Arbitration Act can be set aside for an error of law only if the error is patently unreasonable. The first possible answer is that it has done so. The second is that it has not. The third is that it has made such a holding, but only by way of obiter dictum. Each of these possible answers involves difficulties.

The case for deciding that the Supreme Court has made the "patently unreasonable" test applicable is that that is what it said in the Shalansky case. In rejecting the Saskatchewan Court of Appeal's view that the Volvo decision had put cases involving the construction of collective agreements into a separate category, the Supreme Court said that "the principle on which this so-called third category is founded is the very principle applicable in all consensual arbitration cases". ${ }^{20}$ But private non-labour arbitrations are consensual arbitrations. Therefore, a rule which applies to all consensual arbitrations applies to private non-labour arbitrations. The Supreme Court, it appears, has spoken, and it founded its decision on what it said.

But before accepting this answer, it would be useful to stop to think of the common law, the legislation and the policy which one would expect the Supreme Court to take into account before making such a holding.

First, let us look at the common law. It is enough to note that the Supreme Court itself had previously held that an award in a private nonlabour arbitration can be set aside on the grounds of an error in law, with no requirement that the error must be "patently unreasonable" or even

19. Fort McMurray School District v. Fort McMurray Catholic School District (1984) 9 D.L.R. (4th) 224 (Miller ACJ); Loyal Electric Ltd. v. A.V. Carlson Construction Corp. Ltd. (1985) 39 A.R. 383 (McNaughton J); MacDonald v. United Association of Journeymen (1986) 68 A.R. 165 (Stratton J). In Navigation Sonomar Inc. v. Algoma Steampships Limited, as yet unreported, the Quebec Superior Court said that it did not believe that an award of a private arbitrator "was patently unreasonable and defies Canadian and Quebec law". However, the rule that an award cannot be set aside for error in answering a specific question of law referred to it was an inextricable part of the reason for the decision, and the Quebec jurisprudence appears to be different, so that it is not clear that the decision is relevant in a common law jurisdiction.

20. Supra note 17. 
unreasonable. ${ }^{21}$ No doubt, the Supreme Court can sweep away more than 100 years of English and Canadian decisions and depart from its own previous decisions, but one would expect it to take note of the fact that it is doing so.

Second, let us look at the statutory language involved. The Arbitration Acts provide that the Court may set aside an arbitrator's award if the arbitrator has misconducted himself. This is a grant of power. Privative clauses provide that an arbitrator's award is not judicially reviewable. This is a taking away of power.

The "patently unreasonable" test marks out the boundaries within which the courts will engage in judicial review of the decisions of statutory delegates. If it also marks out the boundaries of judicial review with respect to the awards of arbitrators in private non-labour arbitrations under the Arbitration Act, it must follow that the power which the Alberta Legislature conferred on the Court in 1909 to set aside a private non-labour arbitrator's award for misconduct is the same power which it leaves with the Court nowadays when it enacts a provision restricting judicial review of the decisions of statutory delegates. It would of course be possible for the Supreme Court to hold that the intention, or the effect of the language in which it is expressed, is the same in both cases. One would, however, expect the court to refer to the apparent difference in the statutory language, if only to say that the different words lead to the same result.

Third, let us look at the underlying policy. The "patently unreasonable" test would give effect to a firm judicial policy of leaving arbitration awards alone except in extreme cases, and that may be a very good policy indeed. The "patently unreasonable" test was, however, devised to reconcile legislative policies embodied in privative clauses and judicial policy embodied in judicial review. There is nothing to prevent the Supreme Court of Canada from taking a test which it has devised in order to give effect to one policy and using it to give effect to another policy, but one would expect it to take note of the fact that it is doing so.

It is not fair to attribute to the Supreme Court an intention to depart from established jurisprudence, including decisions of its own, without saying so. It is not fair to attribute to it an intention to apply decisions based upon legislation restricting judicial review to legislation conferring power to set aside awards for misconduct without noticing that that is what it was doing. It is not fair to attribute to it an intention to adopt a new judicial policy towards private non-labour arbitrations without mentioning either the new policy or that it was departing from previous judicial policy. ${ }^{22}$ More to the point, it is not safe to attribute such intentions to it. Faced with an existing cluster of clear and specific Supreme Court of Canada authorities based on the "error of law on the face of the record" test, on the one hand, and one Supreme Court decision of dubious

21. E.g., McRae v. Lemay (1889) 18 S.C.R. 280; Faubert v. Watts [1960] S.C.R. 235; City of Vancouver v. Brandram-Henderson of BC Ltd. [1960] S.C.R. 539; Scotia Construction Co. Ltd. v. City of Halifax [1966] S.C.R. 581. In the Scotia Construction case, Chief Justice Duff did say that the error must be "manifest", but that is different from saying that it must be "unreasonable".

22. This seems to be the same feeling as that which oppressed Mr. Justice Kerans in the R.O.M. case, supra note 5. 
applicability to private non-labour arbitrations, on the other, it seems unsafe to prefer the doubtful decision to the cluster on the mere grounds that it came somewhat later. That this is so is emphasized by an obiter dictum of Mr. Justice Lamer ${ }^{23}$ which, though the case before the court arose under Quebec law, does not appear to be confined to Quebec law. Having held that even in the face of a privative clause an unreasonable finding either of fact or law affects the jurisdiction of the tribunal, he went on to say this:

I hasten to add that the distinction between an error of law and one of fact is still entirely valid when the tribunal is not protected by a privative clause. Indeed, though all errors of law are then subject to review, only unreasonable errors of fact are, but no others.

The better course, in the writer's submission, is to treat the Supreme Court's remarks in the Shalansky case as being directed to the kind of case before it, namely, a labour arbitration case, though one which was characterized as consensual. There is no reason to think that the argument that the "patently unreasonable" test should apply to awards in private non-labour arbitrations was put before the court. When it spoke of "consensual" arbitrations the court could have had in mind "consensual" arbitrations to which labour relations legislation applies. The better course, until the court addresses its mind to the subject, is to conclude that if it had meant to talk about private non-labour arbitrations it would have said so.

\section{THE "FINAL AND BINDING" PROVISION}

There is one final question to notice. Section 8 of the Schedule to the Arbitration Act reads as follows: "The award to be made by the umpire or arbitrator shall be final and binding on the parties and the persons claiming through them.' In the Fort.McMurray case, Associate Chief Justice Miller said: $:^{24}$

Clearly, this is a finality clause, the effect of which is, in Laskin C.J.C.s words, to "cast

a gloss on the extent to which decisions of the Board may be overturned by a court".

Mr. Justice McNaughton in the Loyal Electric cases used similar language, and Mr. Justice Stratton in the MacDonald case ${ }^{26}$ also referred to what Chief Justice Laskin had said.

Those words of Chief Justice Laskin come from his decision in AUPEv. Board of Governors of Olds College ${ }^{27}$. In that case, section 9(1) of the Public Service Employee Relations Act provided that a decision of the Public Service Employee Relations Board was final and binding; section 11 provided that the Board had exclusive jurisdiction to decide all questions of fact or law; section 89(1) provided that no award was to be questioned in any court, but did not include certiorari and mandamus in the list of specific devices by which an award was not to be questioned; and section 89 (2) provided that, notwithstanding section 89(1), a decision of the Board could be questioned by certiorari or mandamus if the application was filed within 30 days of the award.

23. Blanchard v. Control Data Canada Ltd. [1984] S.C.R. 476, 495. Emphasis added.

24. Supra, note 19, at page 233.

25. Supra, note 19.

26. Supra, note 19.

27. [1982] 1 S.C.R. 923. 
Section 8 of the Schedule to the Arbitration Act is not (as was section 9(1) of the PSER Act) a legislative decree. It depends for its effect on section 2 of the Arbitration Act: "A submission, unless a contrary intention is expressed in it, ... shall be deemed to include the provisions set out in the Schedule so far as applicable to the reference under the submission". Section 8 is therefore a term implied in the contract under which a private non-labour arbitration takes place.

Chief Justice Laskin attributed "commanding" effect to the legislative decrees contained in section 9(1) and 11 of the PSER Act. Would he have attributed the same commanding effect to a term implied by statute in a contract? It seems unsafe to conclude that he would, or to conclude that the Olds College case is authority for the proposition that the implied term ousts the jurisdiction of the court in those cases in which an award is manifestly wrong but is not patently unreasonable. The courts have traditionally resisted the ousting of their jurisdiction by mere terms in arbitration agreements.

Even more important is the jurisprudence. The prototype of section 8 was in the Schedule to the Arbitration Act 1889 (UK) and it has been carried forward in the Canadian Acts. English and Canadian courts have uniformly held that they nevertheless had jurisdiction to set aside awards for error of law on the face of the award. ${ }^{23}$ The applicability of the Olds College case to a private non-labour arbitration is, in my submission, even more dubious than is the applicability of the Shalansky case, and it is even more unsafe to attribute to the Supreme Court in the Olds College case the intention of adopting a new policy for private non-labour arbitrations without referring to the jurisprudence, to the legislation or to the underlying policy.

It is my submission that the contractual term implied by section 8 in the Schedule to the Arbitration Act does not deprive the Queen's Bench of the statutory power to set aside an award for misconduct which section 11(2) of the Act confers upon it.

\section{WHEN THE "PATENTLY UNREASONABLE" TEST APPLIES}

The courts will not leave undisturbed every arbitrator's award which is based upon an answer to a question of law which is wrong but not patently unreasonable. The Supreme Court of Canada has held that an error on the face of the award in the interpretation of a public statute is enough grounds to set aside an award..$^{29}$ The Alberta Court of Appeal has said the same about a wrong application of the doctrine of promissory estoppel. ${ }^{30}$

Some awards based upon wrong but not patently unreasonable answers will be protected. Others will not. The decisions which have been reviewed in this note do not provide a touchstone to distinguish the members of the

28. See, e.g., the Supreme Court of Canada cases mentioned supra note 21 and the R.O.M. case, supra note 5.

29. McLeod v. Egan [1975] 1 S.C.R. 517.

30. Smoky River Coal Limited v. United Steelworkers of America (1985) 60 A.R. 36, 41 (Alta. C.A.). In Mr. Justice Stevenson's view, the misconception of the only legal principle which supports the result means that an award must be set aside because it cannot be rationally supported. This was obiter dictum. 
better-protected species. They do, however, have something to say on the subject.

In McLeod v. Egan ", Mr. Justice Martland, speaking for the majority, simply said that there was an error of law on the face of the award in respect of a statutory provision and reversed the court below, which had upheld the award. Chief Justice Laskin, giving the separate concurring reasons of himself and Spence and Beetz JJ., referred to the approach taken below, namely, that there was an issue of construction and that the construction adopted by the arbitrator was one which the language he was construing could reasonably bear. He then went on:

Although the issue before the arbitrator arose by virtue of a grievance under a collective agreement, it became necessary for him to go outside the collective agreement and apply a statute which was not a projection of the collective bargaining relations of the parties but a general public enactment of the superior provincial Legislature. On such a matter, there can be no policy of curial deference to the adjudication of an arbitrator, chosen by the parties or in accordance with their prescriptions, who interprets a document which is in language to which they have subscribed as a domestic charter to govern their relationship.

It seems that a question of the interpretation of the contract between the parties falls within the better-protected class of questions of law. If there is to be such a class, the inclusion of such questions in it is understandable. The meaning of a contract is a question of law - the courts have always said so - but it is a question which involves the parties alone and which involves an investigation of their intentions and conduct to such an extent that it has much of the quality of a question of fact. Chief Justice Laskin appears to have been making some such point in McLeod v. Egan. In the Olds College case, ${ }^{32}$ the Chief Justice included a question of statutory interpretation in the better-protected class but this was because, in his view, the interpretation and application of the statutory provisions had been peculiarly committed to the Board whose decision was under attack. It does not appear that for private non-labour arbitrations the betterprotected class, if it exists, has so far been extended to include anything but questions of interpretation of contracts.

\section{CONCLUSION}

Does the difference between setting aside an arbitrator's award for manifest error of law on the face of the record, on the one hand, and setting it aside only if it is patently unreasonable, on the other, matter very much? Maybe it is only a semantic question which does not justify the time and energy spent on it, including this lengthy note. Chief Justice Laskin in the Shalansky case came close to saying that it is a mere semantic question. But it does seem that there is a difference of substance. Some awards which would be set aside under an "error of law" test will survive a "patently unreasonable" test.

If there is a difference, which test is best? That is beyond the scope of this note. The answer which will be given is likely to be based upon the general view of the person answering it about the relative positions of the arbitration system and the judicial system. Those who think that private non-labour arbitration is an alternative form of dispute resolution which

31. Supra, note 29.

32. Supra, note 27. 
should be left as much to itself as possible are likely to prefer the "patently unreasonable" test because it restricts the scope of judicial review. Those who regard the judicial system as the primary dispenser of justice and protector of the rights of the citizen are likely to prefer the broader "error of law on the face of the record" test and to rely on the courts, in the exercise of sound judicial discretion, to distinguish between awards which should be upheld and awards which should be set aside.

Which test does the law say that the courts should apply? On the side of the "error of law on the face of the award" test is a hundred years of jurisprudence, including a number of specific pronouncements by the Supreme Court of Canada. On the side of the "patently unreasonable" test is one rather doubtful abstract pronouncement by the Supreme Court of Canada in the Shalansky case and its acceptance by three Alberta Queen's Bench judges, buttressed by a much more doubtful interpretation of the Olds College case. This situation is unsatisfactory. It is to be hoped that someone with the power to resolve it, whether court or legislature, will do so. The British Columbia Legislature has already done $\mathrm{so}^{33}$ by providing an appeal process which will not give rise to these doubts. So has the Parliament of the United Kingdom. ${ }^{34}$

33. Commercial Arbitration Act, SBC 1986 c. 3, s. 31(1). The appeal is by leave and can only be taken if the arbitration is important to the parties and a miscarriage of justice may be prevented, or if the point of law is important to a class or to the public.

34. Arbitration Act 1979 (UK) s. 1. 